\title{
The influence of season and volatile compounds on the acceptance of introduced European honey bee (Apis mellifera) Queens into European and Africanized colonies*
}

\author{
Gloria DeGRANDI-HOFFMAN ${ }^{\mathrm{a}}$, David GILLEY ${ }^{\mathrm{a}}$, Judith HoOPER ${ }^{\mathrm{b}, \mathrm{c}}$ \\ ${ }^{a}$ Carl Hayden Bee Research Center, USDA-ARS, 2000 East Allen Road, Tucson, AZ 85719, USA \\ ${ }^{\mathrm{b}}$ Pima Research, PO Box 65626, Tucson, AZ 85728, USA \\ ${ }^{c}$ ARL Division of Neurobiology, University of Arizona, PO Box 210077, Tucson, AZ 85721, USA
}

Received 27 June 2006 - Revised 28 September 2006 - Accepted 28 September 2006

\begin{abstract}
Mated European honey bee (Apis mellifera) queens were introduced into Africanized and European colonies to determine if acceptance rates differed. Prior to introduction, volatile compounds emitted by queens were collected. More queens were accepted by European colonies compared with Africanized. The highest supersedure rate occurred in Africanized colonies during summer introductions. Queen acceptance did not differ between European and Africanized colonies during spring or fall introductions. E- $\beta$-ocimene was the only compound consistently detected in queens prior to their introduction, and was present in lower amounts in queens that were rejected within the first week of their introduction. The best time to introduce European queens appears to be in the fall when overall rejection rates are the lowest.
\end{abstract}

honeybee queen / Africanized bee / pheromone / E-B-ocimene / queen acceptance / Apis mellifera

\section{INTRODUCTION}

European honey bee (EHB) colonies become Africanized when their queens mate with African drones. The presence of African patrilines in a colony causes it to exhibit some of the typical Africanized honey bee (AHB) behaviors particularly extreme nest defense (Guzman-Novoa and Page, 1993; DeGrandiHoffman et al., 1998; Guzman-Novoa et al., 2005). To reverse the Africanization process and alleviate the undesirable behaviors, an EHB queen mated with EHB drones needs to be introduced and accepted by the colony.

Honey bee colonies do not readily accept a queen that is not their own. If a colony loses its queen, workers can either rear new ones (from worker eggs or larvae already existing in

Corresponding author: G. DeGrandi-Hoffman, gdhoff@aol.com; gd-hoffman@ tucson.ars.ag.gov

* Manuscript editor: Stan Schneider the colony) or a new queen can be introduced artificially. There are many devices and protocols to successfully introduce EHB queens into EHB colonies. However, there are anecdotal reports that the success rate of introducing $\mathrm{EHB}$ queens into $\mathrm{AHB}$ colonies is low. Whether the acceptance and retention of EHB queens by AHB colonies actually differs from that of EHB colonies under the same conditions has not been documented.

One factor that influences queen acceptance by a colony is the compounds she emits to communicate her presence (Breed, 1981; Boch and Morse, 1982; Moritz and Crewe, 1988; Breed and Stiller, 1992). Queens produce and emit numerous compounds from glands and regions of their bodies that workers use to identify the queen (e.g., Velthuis, 1970; Slessor et al., 1988; Moritz and Crewe, 1991; Keeling et al., 2003). Recently, unique volatile compounds emitted from queens have been described. The appearance and amounts 
of the compounds differ depending upon factors such as time of year and colony conditions (Gilley et al., 2006). The amounts of one compound, E- $\beta$-ocimene, varies with mating status (Gilley et al., 2006).

The purpose of this study was to compare the acceptance and retention rates of introduced mated EHB queens in AHB and EHB colonies during different times of year and colony conditions. All introduced queens were commercially produced and mated with EHB drones. We also investigated whether there is a relationship between the presence and amounts of certain volatile compounds emitted by queens and their acceptance by EHB and AHB colonies.

\section{MATERIALS AND METHODS}

\subsection{Queen introductions and colony inspections for queen acceptance}

The study was conducted at the Carl Hayden Bee Research Center in Tucson, Arizona in 2003 and 2004. Queens were introduced in 16 colonies (8 EHB and 8 AHB) per trial. The eight AHB colonies were headed by European matriline queens that were produced from natural queen replacement. The queens mated in the Tucson area with African drones. Africanization was confirmed by morphometric analysis of worker bees (probability of Africanization > 0.9 for all colonies with openmated queens) (Rinderer et al., 1993). The eight EHB colonies were headed by commercially produced queens purchased from Big Island Queens in Captain Cook, Hawaii that were marked prior to introduction.

Queens that were introduced into the European or Africanized colonies were commercially produced and purchased from the same queen breeder as above. In 2003, the queens were introduced into 5 -frame colonies while in 2004, queens were introduced into standard 9-frame colonies. Queens were introduced into colonies at three different times of year: May (spring) during a period of surplus nectar and pollen availability, July (summer) when there was no surplus nectar but brood was being reared at rates so that colony populations were increasing, and October (fall) when brood rearing was on the decline. Empty comb or nectar and pollen were provided if necessary during each colony inspection so that neither food nor space was limiting. Different European and Africanized colonies were used for each of the trials so that data were collected from a total of 485 -frame colonies and 329 -frame colonies.

Africanized and European colonies were similar in population size at the time when queens were introduced in each trial. In all cases, 5-frame colonies had 2-3 frames with brood, 1-2 empty frames and a frame with honey and pollen. 9-frame colonies had 3-4 frames with brood, 1-2 empty frames and 34 frames with stored resources. The frames were covered with bees so that the 5 -frame colonies had 4500-5500 worker bees and 9-frame colonies had 9000-10000 workers. Adequate space was available on the frames for the introduced queen to lay eggs.

Queens were removed from their colonies 72 $96 \mathrm{~h}$ before introducing the new queens. Just before the queens were introduced, the frames in the colony were examined and any cells containing larvae that workers were rearing into queens were removed. The new queens were housed in standard pine shipping cages. Queens were introduced into colonies using the standard beekeeping practice of placing the cages between the center frames of the hive. The introduced queen was marked with a dab of paint on the dorsum of her mesothorax. The queens were released into the colony when workers chewed through the sugar-candy plug in the cage. Colonies were examined for the presence of the queen seven days after she was introduced. If the queen was found, the colony was examined weekly for the next six weeks or until the queen or eggs were no longer present. The six week period was chosen as an indicator of queen retention because by this time most of the workers that were progeny of the original queen had died and the worker population was comprised mostly if not entirely of offspring of the introduced queen. During the colony inspections, we noted the presence of queen cells containing larvae (supersedure cells). The fate of each queen cell was recorded in subsequent observations.

\subsection{Collection and analysis of volatile compounds from queens}

Volatile compounds emanating from queens were sampled using solid phase microextraction (SPME) devices (Gilley et al., 2006). Previous work in our laboratory determined that a $65 \mu \mathrm{m}$ polydimethylsiloxane-divinylbenzene fibre (Supelco SPME fibre 57326U) yielded 


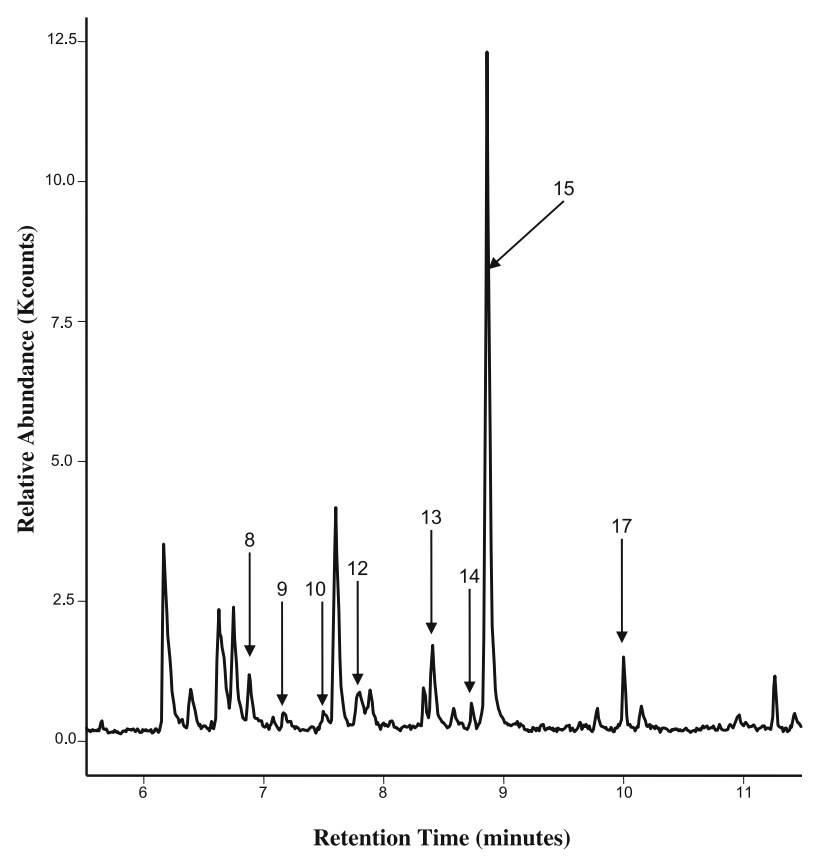

Figure 1. Chromatogram showing the eight peaks that were often present in shipped, mated European honey bee queen immediately prior to introducing them into colonies. chromatograms with the most numerous and largest peaks.

Queens were placed in clean $50 \mathrm{~mL}$ glass Erlenmeyer flasks shaded from light with aluminium foil. The flasks were fitted with a wire cage insert that surrounded the fibre to prevent physical contact between the queen and the fibre during sampling. Volatiles were collected for $10 \mathrm{~min}$ at room temperature and approximately $35 \%$ relative humidity. The fiber was immediately injected into the GC/MS (Varian CP-3800 GC/Saturn $2200 \mathrm{MS}$ system) and desorbed for $3 \mathrm{~min}$ at $240{ }^{\circ} \mathrm{C}$ in splitless mode. The compounds were separated on a Varian FactorFour VF-5ms $30 \mathrm{~m} \times 0.25 \mathrm{~mm}$ column with the following programmed parameters: column temperature $40{ }^{\circ} \mathrm{C}$ for $3 \mathrm{~min}$, then ramped to $250{ }^{\circ} \mathrm{C}$ at $15 \mathrm{de}-$ grees per minute; helium flow rate $1 \mathrm{~mL} / \mathrm{min}$. The MS was operated in EI mode at $150 \mathrm{eV}$, or in CI mode at $10 \mathrm{eV}$ using acetonitrile as the chemical ionization agent. GC/MS data were collected and processed using Saturn Workstation v. 5.52 software (Varian Analytical Instruments).

Samples of volatile compounds emanating from queens were collected just prior to their introduction into colonies. In addition to the queens, we also sampled the volatiles from the shipping cages that housed the queens. The cages were sampled by exposing a SPME fiber for $10 \mathrm{~min}$, suspended approximately $1 \mathrm{~cm}$ over the cage. This allowed us to eliminate peaks from the analysis that originated from the sampling environment or the cage itself. Samples also were taken from a set of established EHB and AHB queens just prior to their removal. We examined the chromatograms for compounds that were specific to queens as determined by earlier studies (Gilley et al., 2006).

\subsection{Statistical analysis}

We compared the frequency that EHB and AHB colonies accepted introduced queens during Year1 and Year-2, to determine if acceptance rates differed between years. We divided queen acceptance into two stages. Stage-1 was acceptance during the first week after introduction when the queen is in the process of being released from the cage and is beginning to lay eggs. Stage-2 included weeks 2 6 after introduction when the queen was becoming established but the colony was only partly comprised of her offspring. We compared the frequency of queen acceptance (stage-1 and -2) between EHB and $\mathrm{AHB}$ colonies during the three introduction periods. We also determined whether the frequency of queen acceptance differed among the introduction times. All comparisons of queen acceptance were made using the G-test for Goodness of Fit (Sokal and Rohlf, 1995). 
The relative amounts of eight volatile compounds (Fig. 1) collected from queens prior to their introduction into colonies were compared between those introduced into AHB and EHB colonies using t-tests with Bonferroni adjustment. Comparisons also were made between relative amounts of compounds collected from queens that were established in EHB and AHB colonies just prior to their removal. Whether amounts of any compound differed between queens that were accepted into either European or Africanized colonies during stage1 or stage- 2 was determined using t-tests. The relative amounts of volatile compounds collected from queens prior to their introduction was compared across all trials using a general linear model that included season of introduction as the dependent variable (Sokal and Rohlf, 1995). Data were transformed with the equation: $\log (\mathrm{x}+1)$ prior to anal$\mathrm{y}$ sis where $\mathrm{x}=$ relative amount of each compound.

\section{RESULTS}

\subsection{Queen acceptance}

The overall acceptance rate of queens did not differ between years $(\mathrm{G}=2.28$, critical value $=3.84$, d.f. $=1, P=0.05$ ), therefore data from both years were combined. More queens were rejected during stage- 1 in AHB colonies compared with $\mathrm{EHB}(\mathrm{EHB}=5 \%$, $\mathrm{AHB}=$ $15 \% ; \mathrm{G}=6.59$, critical value $=3.84$, d.f. $=1$, $P<0.05)$. Overall, acceptance rates of queens into EHB colonies during stage-2 was greater than in AHB colonies $(\mathrm{EHB}=85 \%$, $\mathrm{AHB}=$ $58.5 \% ; \mathrm{G}=10.45$, critical value $=3.84$, d.f. $=$ $1, P<0.05)$.

During stage- 1 , more queens were accepted in EHB colonies compared with AHB colonies during the spring and summer introductions (Fig. 2). However, the differences were not significant. All queens were accepted during stage- 1 in the fall introductions. The acceptance rate of queens during stage- 2 was affected by the season when they were introduced. In the summer, significantly fewer queens were accepted during stage- 2 in AHB colonies compared with EHB $\left(\mathrm{G}_{\text {summer }}=6.22\right.$, critical value $=5.99$, d.f. $=2, P<0.05)$. The stage-2 acceptance rate of queens in EHB and AHB colonies did not differ in the fall and spring $\left(\mathrm{G}_{\text {fall }}=0.76, \mathrm{G}_{\mathrm{spring}}=3.42\right.$, critical value $=5.99$, d.f. $=2, P<0.05)$.
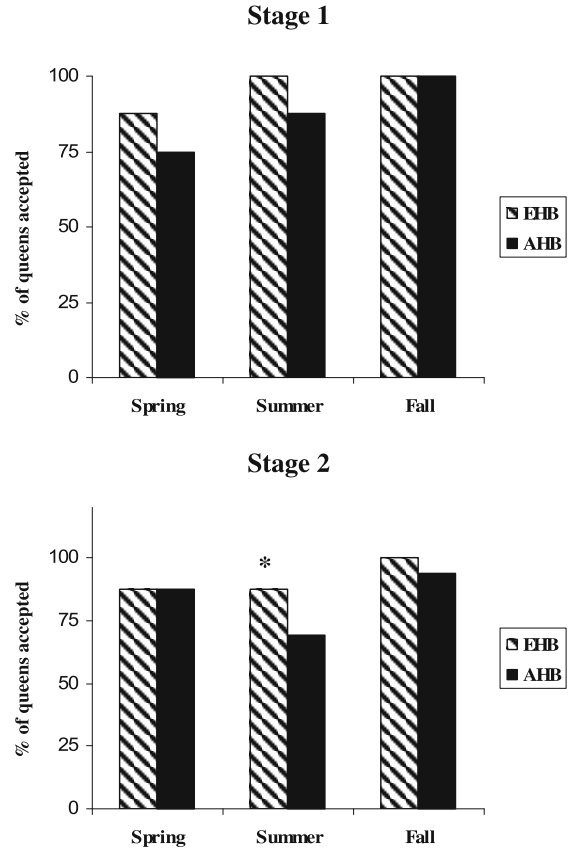

Figure 2. Percentages of queens introduced into European (EHB) and Africanized (AHB) honey bee colonies that were accepted by colonies during stage-1 (1 week after introduction) and stage-2 (2-6 weeks after introduction) during three different seasons. Percentages are based upon 32 colonies per trial in the spring and summer and 16 in the fall. Significant differences in the percentage of queens that were accepted between AHB and EHB colonies as determined by a G-test are marked with an asterisk.

\subsection{Queen volatiles and acceptance}

We detected $8 \mathrm{GC} / \mathrm{MS}$ peaks for all queens, but only five compounds (Peaks 8, 10, 14, $15,17)$ were detected in more than $50 \%$ of the queens prior to their introduction (Fig. 1). These compounds were analyzed further. Peak 8 was previously identified as E- $\beta$-ocimene (Gilley et al., 2006).

Queens introduced into either EHB or AHB colonies were similar in that initial amounts of each compound did not differ between queens (all $P$-values from t-tests $>0.05$ ). Furthermore, samples of volatiles taken from established queens just prior to their removal from the EHB and AHB colonies revealed that average amounts of each compound did not differ 
between the queens from the two colony types (all $P$-values from t-tests $>0.05$ ).

The initial amounts of each compound did not differ between queens that were accepted for the 6-week period and those that were rejected (all $P$-values from t-tests $>0.05$ ). However, a separate analysis of queens that were accepted for the 6 week observation period and those rejected during stage- 1 revealed that queens that were accepted in either EHB or AHB colonies had significantly higher amounts of the $\mathrm{E}-\beta$-ocimene $(\mathrm{t}=2.44$, d.f. $=34, P=0.02$ ) (Fig. 3). Amounts of peak12 (previously identified as 2-phenylethanol (Gilley et al., 2006)) also were greater in accepted queens compared to those that were rejected, but the compound was detected in only $20 \%$ of the queens regardless of whether they were accepted or rejected during stage-1. Other compounds did not differ between the queens that were accepted and those that the workers rejected during stage- 1 .

E- $\beta$-ocimene was the only compound consistently detected in queens prior to their introduction that did not differ in amounts among the seasons (Tab. I). Queens introduced in the summer and fall were more similar in amounts of peaks 14 and 15 than those introduced in the spring. Significantly higher amounts of peak 10 were detected in spring queens compared with those in the summer. We could not detect peak 10 in any of the queens introduced in the fall.

\section{DISCUSSION}

This is the first study to measure the acceptance rates of European queens in Africanized colonies over a 6-week period based upon season when the queen was introduced. The percentage of queens successfully introduced into EHB colonies was significantly higher than in AHB colonies both during the first week after introduction and for the following 6 week period. Overall acceptance rates were highest in both EHB and AHB colonies when queens were introduced in the fall. The percentage of queens that were accepted in AHB and EHB did not differ in the spring or fall. A queen specific compound, E-B-ocimene, that is associated with egg laying, was present in
A

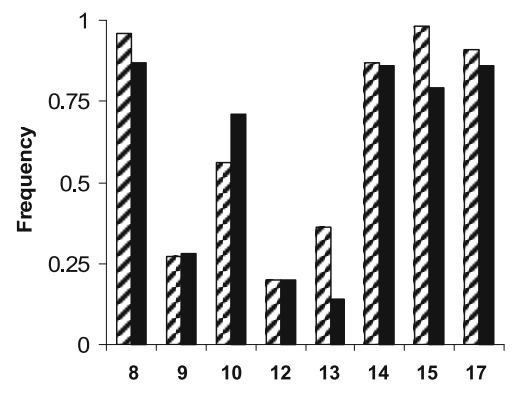

B

- Accepted

- Rejected

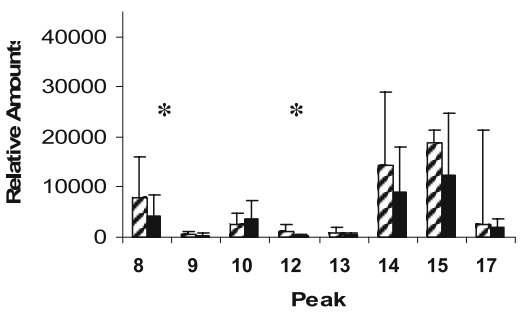

Figure 3. The frequency (A) that volatile compounds (represented by peaks on a chromatogram) were collected from European honey bee queens prior to their introduction into European and Africanized colonies and their relative amounts (B). Average amounts of each compound from queens that were either accepted or rejected during the first week after introduction were compared using t-tests. Compounds with significantly different averages at $P<0.05$ are identified with an asterisk.

higher amounts in queens that were accepted compared with those that were rejected in the first week after introduction.

Previous work with introducing queens into AHB colonies focused on either the acceptance of EHB queens one week after introduction (Guzman-Novoa et al., 1997), or whether the acceptance of selected lines of AHB queens into AHB colonies was affected by applying various treatments to the introduction cages (Guzman-Novoa et al., 1998). The acceptance rate of virgin queens in AHB colonies also has been reported (Moretto et al., 2004). There is about an $80-87 \%$ acceptance rate for mated queens one week after introduction, but the average drops to about $61 \%$ after 6 weeks (Guzman-Novoa et al., 1997, 
Table I. Average relative initial amounts of compounds collected from European honey bee queens prior to their introduction into colonies during different seasons. The compounds are represented by peaks on a gas chromatogram. In all cases averages were estimated from 68 queens.

\begin{tabular}{lccccc}
\hline Peak & \multicolumn{3}{c}{ Average relative amount } & F & $P$ \\
\cline { 2 - 4 } & Spring & Summer & Fall & & \\
\hline 8 & 6644 & 5907 & 7980 & 0.38 & 0.68 \\
10 & $5638 \mathrm{a}$ & $2278 \mathrm{~b}$ & $0.00 \mathrm{c}$ & 21.73 & $<0.0001$ \\
14 & $19619 \mathrm{a}$ & $3222 \mathrm{~b}$ & $2247 \mathrm{~b}$ & 15.47 & $<0.0001$ \\
15 & $5233 \mathrm{a}$ & $27260 \mathrm{~b}$ & $21614 \mathrm{~b}$ & 18.96 & $<0.0001$ \\
17 & $1379 \mathrm{a}$ & $4004 \mathrm{~b}$ & $1768 \mathrm{ab}$ & 6.54 & 0.003 \\
\hline
\end{tabular}

Data were transformed using $\log (x+1)$ prior to analysis. Means followed by the same letter in a row are not significantly different as determined by a Tukey's W Procedure (Sokal and Rohlf, 1995).

1998). Our study had slightly higher initial acceptance rates, but after 6 weeks only about $58 \%$ of the introduced queens were still alive in the AHB colonies. Thus, while queen acceptance might be relatively high in AHB colonies during stage-1, many queens do not survive long enough for the population to be comprised predominantly of the offspring from the introduced queen. Furthermore, the comparable queen acceptance and retention rates of introduced EHB or AHB queens in AHB colonies in this and previous studies (GuzmanNovoa et al., 1998) suggests that rejection of introduced queens could occur at a relatively high frequency in AHB colonies regardless of whether the queen is EHB or AHB.

Whether a queen is accepted and retained by a colony appears to be affected by season. Queen rejection during stage-1 or - 2 was highest in the summer introductions, and lowest in the fall. European and Africanized colonies began with approximately equal worker populations at the time when queens were introduced, so population size at the time of queen introduction probably was not a factor in queen acceptance. However, the amount of brood in the colony after the 6-week study period differed among trials depending upon the time of year. In the summer trials, the colonies' broodnest was expanding so cues associated with a queen's fecundity might have been more readily expressed than for example, in the fall when egg laying rates were declining. Thus, colonies especially AHB, might be less discriminating in the queens they accept during the fall.

Replacing queens in the fall is a common practice in managed colonies. Requeening in the fall is recommended because a young actively laying queen will insure that the colony will have a large number of young bees in the winter cluster (Ambrose, 1992). Requeening AHB colonies in the fall might have the added benefits of improving the chances that the queen will be accepted, and that large numbers of EHB workers will be in the colony the following spring, thus reducing its defensiveness. However, there is risk involved with fall requeening in Africanized areas. Usurpation swarms of African bees can invade European colonies especially if they are queenless or have caged queens as they often do when being requeened (Danka et al., 1992; Schneider et al., 2004). The usurpation swarms most frequently occur in the fall so while it is perhaps the best time to requeen colonies, EHB hives need to be closely monitored to prevent Africanization from usurpation swarms.

In addition to season, queen acceptance also appears to be affected by the volatiles queen produce. Queens that were rejected during stage-1 after introduction had lower levels of E- $\beta$-ocimene and 2-phenylethanol at the time of introduction than queens that were accepted. Amounts of E- $\beta$-ocimene probably have a greater affect on queen acceptance than 2-phenylethanol because it was detected in all queens while 2-phenylethanol was detected in only $20 \%$. 2-phenylethanol is most 
likely to be detected in virgin queens and, to a lesser degree, in those that recently mated (Gilley et al., 2006). The detection of the compound in queens might be indicative of how recently they mated and the length of time that they were laying. Other compounds differed among queens with regard to the season when the queen was introduced, but the amounts of those compounds did not differ between queens that were accepted and those that were rejected. Only E- $B$-ocimene did not differ in initial amounts across the seasons when we introduced queens. However, queen rejection rates did differ among season. Therefore, it is possible that thresholds of E- $\beta$-ocimene for queen acceptance also are dependent on time of year and the state of the colony.

There probably are other environmental and colony factors that could affect the retention of a queen after she is accepted. For example, the degree that a colony is Africanized probably plays a role in queen acceptance. Colonies in our study had a high probability of Africanization that might have made acceptance rates lower than in colonies with fewer workers with African paternity.

The chances that queens will be accepted might be affected by how they are reared. The queens we introduced were the products of grafting rather than the natural queen replacement process. In grafting, most of the larvae placed into queen cups ultimately emerge as queens (Laidlaw, 1979). During natural queen replacement though, many larvae might be reared into queens but only one survives (see Tarpy et al., 2004). Grafted queens could have greater variation in factors associated with queen acceptance and retention than those that are products of the natural queen replacement. We found wide variation among queens even within a single season in the presence and amounts of volatiles we detected. The differences in acceptance rates of introduced queens into EHB and AHB colonies could be because European patriline workers have higher thresholds for factors associated with queen acceptance compared with Africans particularly after the queen begins to lay. Future work will be directed at identifying those factors, and how they might differ between EHB and
AHB colonies at different times of year and colony conditions.

\section{ACKNOWLEDGEMENTS}

We thank Mona Chambers, Thomas Deeby, Delayne Caseman and Maurissa Twotwo for technical support; Corrina Thom, David Tarpy, and two anonymous reviewers for their helpful suggestions on earlier versions of the manuscript. The research was funded by a grant from the Almond Board of California.

Influence de la saison et des composés volatils sur l'acceptation de reines d'abeilles européennes (Apis mellifera) introduites dans des colonies européennes et africanisées.

Apis mellifera / abeille africanisée / acceptation reine / phéromone / E-ß-ocimène / saison

Zusammenfassung - Bedeutung der Jahreszeit und flüchtiger Substanzen für die Annahmequote von Königinnen der europäischen Honigbiene (Apis mellifera) in afrikanisierten Völkern. Eine Afrikanisierung der Honigbienenvölker unter imkerlicher Betreuung kann durch die Einweiselung von mit europäischen Drohnen begatteten europäischen Königinnen verzögert werden. Afrikanisierte Völker akzeptieren neue Königinnen nur mit Schwierigkeiten, aber es wurde bisher nicht untersucht, ob sich die Annahmequote von begatteten europäischen Königinnen bei afrikanischen und europäischen Völkern im Jahresverlauf und in Abhängigkeit vom Zustand der Völker unterscheidet. Wir weiselten europäische Königinnen, begattet von europäischen Drohnen, in europäische und afrikanisierte Völker ein: 1. im Frühjahr, während eines Überangebotes von Nektar und Pollen, 2. im Sommer, während der Erweiterung des Brutnestes und 3. im Herbst während der Einschränkung der Eiproduktion und Aufzucht der Brut. Außerdem sammelten wir flüchtige Stoffe, die von den Königinnen vor ihrer Einweiselung abgesondert wurden, um bestimmte Verbindungen, die möglicherweise bei der Annahmerate eine Rolle spielen könnten, nachzuweisen (Abb. 1). Im Vergleich zu afrikanisierten wurden von den europäischen Völkern mehr Königinnen angenommen (Abb. 2). Afrikanisierte Völker hatten die höchste Rate an Nachschaffungsköniginnen bei Einweiselung im Sommer. Im Frühjahr und Herbst unterschied sich die Annahmerate zwischen den Volkstypen nicht. Die in der ersten Woche nicht angenommenen Königinnen hatten eine geringere Menge von E- $\beta$-Ocimene als die, die für die folgenden 6 Wochen im Volk verblieben. 
E- $\beta$-Ocimene war die einzige Substanz, die immer bei Königinnen vor der Einweiselung nachgewiesen wurde und deren Menge über die volle Saison konstant blieb (Tab. I). Die beste Zeit für eine Einweiselung von europäischen Königinnen scheint im Herbst zu liegen, wenn die Annahmerate in allen Fällen am höchsten ist.

\section{Honigbienenköniginnen / afrikanisierte Biene / Pheromone / E-B-Ocimene / Königinnenakzep- $\operatorname{tanz}$ / Apis mellifera}

\section{REFERENCES}

Ambrose J.T. (1992) Management for honey production, in: Graham J.M. (Ed.), The Hive and the Honey Bee, Dadant and Sons Hamilton, IL, pp. 602-654.

Boch R., Morse R.A. (1982) Genetic factor in queen recognition odors of honey bees, Ann. Entomol. Soc. Am. 67, 709-711.

Breed M.D. (1981) Individual recognition and learning of queen odors by worker honeybees, Proc. Natl. Acad. Sci. 78, 2635-2637.

Breed M.D., Stiller T.M. (1992) Honey bee, Apis mellifera, nestmate discrimination: hydrocarbon effects and the evolutionary implications of comb choice, Anim. Behav. 43, 875-883.

Danka R.G., Hellmich R.L., Rinderer T.E. (1992) Nest usurpation, supersedure and colony failure contribute to Africanization of commercially managed European honey bees in Venezuela, J. Apic. Res. 31, 119-123.

DeGrandi-Hoffman G., Collins A., Martin J.H., Schmidt J.O., Spangler H.G. (1998) Nest defense behavior in colonies from crosses between Africanized and European honey bees (Apis mellifera L.) (Hymenoptera: Apidae), J. Insect Behav. $11,37-45$.

Gilley D.C., DeGrandi-Hoffman G., Hooper J.E. (2006) Volatile compounds emitted by live European honey bee (Apis mellifera L.) queens, J. Insect Physiol. 52, 520-527.

Guzman E., Hunt G.J., Page R.E., Uribe-Rubio J.L., Prieto-Merlos D., Becerra-Guzman F. (2005) Paternal effects on the defensive behavior of honeybees, J. Hered. 96, 376-380.

Guzmán-Novoa E., Page R.E. Jr. (1993) Backcrossing Africanized honey bee queens to European drones reduces colony defensive behavior, Ann. Entomol. Soc. Am. 86, 352-355.
Guzmán-Novoa E., Page R.E. Jr., Correa-Benitez A. (1997) Introduction and acceptance of European queens in Africanized and European honey bee (Apis mellifera L.) colonies, Am. Bee. J. 137, 667668.

Guzmán-Novoa E., Page R.E. Jr., Prieto-Merlos D. (1998) Queen introduction, acceptance, and survival in honey bee (Hymenoptera: Apidae) colonies of a Tropical, Africanized region, J. Econ. Entomol. 91, 1290-1294.

Keeling C.I., Slessor K.N., Higo H.A., Winston M.L. (2003) New components of the honey bee (Apis mellifera L.) queens retinue pheromone, Proc. Natl. Acad. Sci. (USA) 100, 4486-4491.

Laidlaw H.H. Jr. (1979) Instrumental insemination of queens, Dadant and Sons, Hamilton, IL.

Moritz R.F.A., Crewe R.M. (1988) Chemical signals of queens in kin recognition of honeybees (Apis mellifera L.), J. Comp. Physiol. A 164, 83-89.

Moritz R.F.A., Crewe R.M. (1991) The volatile emission of honeybee queens (Apis mellifera L), Apidologie 22, 205-212.

Morretto G., Guerra J.C.V., Kalvelage H., Espindola E. (2004) Maternal influence on the acceptance of virgin queens introduced into Africanized honey bee (Apis mellifera) colonies, Genet. Mol. Res. 3, 441-445.

Rinderer T.E., Buco S.M., Rubink W.L., Daly H.V., Stelzer J.A., Riggio R.M., Baptista F.C. (1993) Morphometric identification of Africanized and European honey bees using large reference populations, Apidologie 24, 569-585.

Schneider S.S., Deeby T., Gilley D.C., DeGrandiHoffman G. (2004) Seasonal nest usurpation of European colonies by African swarms in Arizona, USA, Insectes Soc. 51, 359-364.

Slessor K.N., Kaminski L.A., King G.G.S., Borden J.S., Winston M.L. (1988) Semiochemical basis for retinue response to queen honey bees, Nature 332, 354-356.

Sokal R.R., Rohlf F.J. (1995) Biometry, W.H. Freeman and Company, New York.

Tarpy D.R., Gilley D.C., Seeley T.D. (2004) Levels of selection in a social insect: a review of conflict and cooperation during honey bee (Apis mellifera) queen replacement, Behav. Ecol. Sociobiol $55,513-523$

Velthuis H.H.W. (1970) Queen substances from the abdomen of the honey bee queen, Z. Vgl. Physiol. $70,210-222$. 